\title{
DEVELOPMENT AND METHODOLOGY FOR THE ESTIMATION OF BISAPROLOL IN PHARMACEUTICALS
}

Introduction. The number of drugs introduced into the pharmaceutical market is increasing every year. These drugs may be either new entities or partial structural modification of the existing one. The objective of any analytical measurement is to obtain consistent, reliable and accurate data. Thin layer chromatography, or TLC, is a method for analyzing mixtures by separating the compounds in the mixture. TLC can be used to help determine the number of components in a mixture, to identity of compounds, and the purity of a compound.

The aim of the study. Analysis of Bisoprolol is described in Pharmacopeia but aim of our researches was to improve simpler, selective, more accurate, precise, reliable, less expensive methods by TLC of Bisoprolol in pharmaceuticals and for using this methods for analysis of their metabolites in next step of researches.

Research Methods. The present study is assessed system solvents of Bisoprolol for thin layer chromatography.

Results and Discussion. Method of identification of Bisoprolol in medicines by TLC was developed. It was established that the most optimal Rf observed using mobile phases: ammonia (25\%) - propanol (30:70). The detection limits of Bisoprolol in this system is $0.4 \mathrm{mcg}$. We explored the validation characteristics - specificity and suitability of the chromatographic system that met, the eligibility criteria established by the SPU.

Conclusions. We developed the chromatographic method of identification of Bisoprolol in pharmaceuticals. The proposed method is economical, simple and applicable to the analysis of pharmaceutical dosage forms.

KEY WORDS: Bisoprolol; medicinal drugs; identification; thin layer chromatography; validation.

INTRODUCTION. The number of drugs introduced into the pharmaceutical market is increasing every year. These drugs may be either new entities or partial structural modification of the existing one. The objective of any analytical measurement is to obtain consistent, reliable and accurate data. Bisoprolol, marketed under the trade name Zebeta or Concor among others, (RS)-1-\{4[(2-isopropoxyethoxy)methyl] phenoxy\}-3-(isopropylamino) propan-2-ol, is a medication most commonly used for heart diseases. This specifically includes high blood pressure, chest pain from not enough blood flow to the heart, and heart failure. Bisoprolol is in the $\beta$-blocker family of medications and is of the $\beta_{1}$-selective type [1].

Thin layer chromatography, or TLC, is a method for analyzing mixtures by separating the compounds in the mixture. TLC can be used to help determine the number of components in a mixture, to identity the compounds, and the purity of a compound. By observing the appearance of a product or the disappearance of a reactant, it can also be used to (c) L. S. Logoyda, 2017. monitor the progress of a reaction. Thin layer chromatography TLC is a popular technique for the analysis of a wide variety of organic and inorganic substances, because of its distinct advantages such as minimal sample clean-up, wide choice of mobile phases, flexibility in sample distinction, high sample loading capacity and low cost. The use of chromatographic techniques for monitoring the starting materials, intermediates and the process reactions is an excellent means for controlling the purity of the final drug and thereby protecting the patient who ultimately receives it. TLC is a powerful tool for screening unknown materials in bulk drugs. It provides a relatively high degree of assurance that all possible components of the drug are separated. The high specificity of TLC has been exploited to quantitative analytical purpose using spot elution followed by spectrophotometric measurement. TLC plays a crucial role in the early stage of drug development when information about the impurities and degradation products in drug substance and drug product is inadequate. Various impurities of pharmaceuticals were identified and determined using TLC [2]. 
The aim of the present study was to improve to more rapid, simple, selective, more accurate, less expensive methods TLC analysis of Bisoprolol in pharmaceuticals and for using these methods for analysis of their metabolites in next step of researches.

RESEARCH METHODS. Using this technique, we analyzed medicines "BISOPROLOL-RATIOPHARM" (tablets containing $10 \mathrm{mg}$ of Bisoprolol produced by "Ratiopharm") and "CONCOR" (10 mg tablets of Bisoprolol produced by "Merck KGaA for Nycomed").

Analytical equipment

Scales AVT-120-5D, measuring vessel glass and reagents that meet the SPU requirements. TLC test was carried out using Silica gel, chromatographic plates 60 F254 "Merck" (Germany) and "Sorbfil" (Russia).

Sample of preparation for captopril

Investigation solutions from tablets "BISOPROLOL-RATIOPHARM" and "CONCOR". To sample powder tablets or powder, equivalent to $5.00 \mathrm{mg}$ bisoprolol, add $5.0 \mathrm{ml}$ of methanol $R$ and dilute with methanol $R$ to $10.0 \mathrm{ml}$, mix and filter.

Reference solution. $5.00 \mathrm{mg}$ Pharmacopoeial standard sample SPU of Bisoprolol dissolved in methanol $R$ and dilute with the same solvent to $10.0 \mathrm{ml}$. (30:70).

Mobile phase: ammonia (25 \%) - propanol

Samples that are applied: $5 \mu$, applied the test solution and investigation solutions.

Over a path of $10 \mathrm{~cm}$ from the starting line.

Detection: examination in ultraviolet light at $254 \mathrm{~nm}$.

RESULTS AND DISCUSSION. The present study assessed the different solvent extracts of Bisoprolol for thin layer chromatography TLC. The chromatogram obtained with the test solution is detected at the main spot basic substance in the chromatogram obtained with reference solution, corresponding in size and color. We had investigated various mobile phases (solvent system) in order to identify the optimal choice of Bisoprolol investigation by TLC in medicines. The factors of mobility in the studied of Bisoprolol in mobile phases are listed in Table.

We found that for identification by TLC using a sensitive of all investigated solvents. It was established that the most optimal Rf was observed using mobile phases for Bisoprolol: ammonia (25\%) - propanol (30:70). The detection limit of Bisoprolol in this system is $0.4 \mathrm{mcg}$. The analysis considered probable, though the test requirements "Check suitability chromatographic system". Che- cking the suitability of the chromatographic system. Chromatographic system is considered appropriate when:

- the chromatogram obtained with reference solution is a clearly visible spot;

Rf principle spot in the chromatogram obtained with reference solution to be about 0.6.

We previously studied the behavior of placebo tablets in terms of methods of identification of Bisoprolol. It was established that the excipients are part of tablets and do not affect the sensitivity and specificity of Bisoprolol detection. Validated analytical methods play an important role in achieving this goal. The results from method validation can be used to judge the quality, reliability and consistency of analytical results, which is an integral part of any good analytical practice. Validation of analytical methods is also required by most regulations and quality standards that impact laboratories [3]. Very often there is a time lag from the date of introduction of a drug into the market to the date of its inclusion in pharmacopoeias. This happens because of the possible uncertainties in the continuous and wider usage of these drugs, reports of new toxicities, development of patient resistance and introduction of better drugs by competitors. Under these conditions, standards and analytical procedures for these drugs may not be available in the pharmacopoeias. There is a scope, therefore to develop newer analytical methods for such drugs. According to the SPU and Note for guidance on validation of analytical procedures: text and methodology (CPMP/ICH/381/95) to test the Identification must be validated, to determine such characteristics as specificity and suitability of the chromatographic system. The maximum difference of Rf values in the same plate (for two series of plates) must not exceed the value of 0.02 . Originally, plates were tested according to the requirements of SPU on chromatographic resolution. When checking for the stability of the solution at the time we started chromatography of Bisoprolol freshly prepared test solution sustained, over time for 30 min. Visual assessment of spots on the size and intensity of staining confirms that they clearly appear as freshly cooked and seasoned in time solutions (for plates of different series). The solutions were stable over time and new areas, had been identified. Thus, we explored the validation characteristics specificity and suitability of the chromatographic system that met, the eligibility criteria established by the SPU. The objective of any analytical measurement is to obtain consistent reliable and accurate data. Analytical method validation is a major issue in the pharmaceutical industry for controlling drug quality, development, and registration. Simply, it is used to justify the analytical method, methods 
Table - Chromatographic characteristics of Bisoprolol in different solvent systems

\begin{tabular}{|l|c|c|c|c|}
\hline \multicolumn{1}{|c|}{ Mobile phase } & $\begin{array}{c}\text { Stationary phase } \\
\text { (plate) } \\
\text { Rf on "Sorbfil" }\end{array}$ & $\begin{array}{c}\text { The limit } \\
\text { of detection, } \\
\text { micrograms }\end{array}$ & $\begin{array}{c}\text { Detection } \\
\text { in ultraviolet light } \\
\text { at 254 nm }\end{array}$ & $\begin{array}{c}\text { Detection } \\
\text { in ultraviolet light } \\
\text { at 365 nm }\end{array}$ \\
\hline chloroform-methanol (9:1) & 0.85 & 0.4 & violet & blue \\
\hline chloroform-ethanol (8:2) & 0.80 & 0.4 & violet & blue \\
\hline $\begin{array}{l}\text { chloroform-methanol-ammonia } \\
(25 \%)(4: 4: 2)\end{array}$ & 0.76 & 0.4 & violet & blue \\
\hline n-butanol-methanol (3:2) & 0.68 & 0.4 & violet & blue \\
\hline $\begin{array}{l}\text { ammonia (25\%)-propanol (30:70) } \\
\text { chloroform-ethanol-ammonia } \\
(25 \%)(20: 5: 1)\end{array}$ & 0.47 & 0.4 & violet & blue \\
\hline $\begin{array}{l}\text { ethyl acetate-methanol-ammonia } \\
(25 \%)(4: 4: 2)\end{array}$ & 0.89 & 0.4 & violet & blue \\
\hline $\begin{array}{l}\text { n-butanol-acetic acid-water } \\
(40: 10: 10)\end{array}$ & - & - & - & - \\
\hline $\begin{array}{l}\text { n-butanol-acetic acid-water } \\
(40: 10: 20)\end{array}$ & - & - & - & - \\
\hline
\end{tabular}

submitted as a part of a new drug application, bioequivalence and bioavailability studies, and for the analysis of drugs as raw material or in their dosage forms [4-6]. Therefore, the present study provided a suitable as well as accurate method for determination of Bisoprolol, which is of potential practical significance.

CONCLUSIONS. We developed TLC methods of identification of Bisoprolol in pharmaceuticals. We found that Bisoprolol identification by TLC using a sensitive of all investigated solvents. It was established that the most optimal Rf was observed using mobile phases for Bisoprolol: ammonia (25\%) - propanol (30:70). The detection limit of Bisoprolol in this system is $0.4 \mathrm{mcg}$. The validation study of the characteristics of both specificity and suitability of the chromatographic system, confirmed that they meet the eligibility requirements under the SPU. Prospects for future research will be aimed at developing methods of the analysis Bisoprolol metabolites by proposed TLC.

\section{LIST OF LITERATURE}

1. www.medicines.org.uk

2. Review on analytical method development and validation. Research and reviews / R. Patil, T. Deshmukh, V. Patil, K. Khandelwal // Journal of Pharmaceutical Analysis. - 2014. - № 3 (3). - P. 1-10.

3. ICH Topic Q2 (R1) Validation of analytical procedures: text and methodology.

4. Liliya L. Development of methods for identification of calcium channel blockers in medicines / L. Liliya, K. Dmutro, S. Stanislav // International Journal of Research Ayurveda Pharmaceutical. - 2016. - № 7 (2). P. 88-91.

\section{REFERENCES}

1. www.medicines.org.uk

2. Patil, R., Deshmukh, T., Patil, V., \& Khandelwal, K. (2014). Review on analytical method development and validation. Research and reviews. Journal of Pharmaceutical Analysis, 3 (3), 1-10.

3. ICH Topic Q2 (R1) Validation of Analytical Procedures: Text and methodology.

4. Liliya, L. Dmutro, K., \& Stanislav, S. (2016). Development of methods for identification of calcium channel blockers in medicines. International Journal of Research Ayurveda Pharmaceutical, 7 (2), 88-91.
5. Logoyda L. Development and validation of new methods of analysis for the determination of different natural and synthetic original active pharmaceutical ingredients in medicines / L. Logoyda // Duphat. - 2015. P. 48.

6. Logoyda L. Validation of chromatographic methods of analysis for the determination of active pharmaceutical ingredients in different medicines / L. Logoyda // Pharma School association for pharmaceutical development and scientific research. Egypt. - 2016. - P. 34.

5. Logoyda, L. (2015). Development and validation of new methods of analysis for the determination of different natural and synthetic original active pharmaceutical ingredients in medicines. Duphat, 48.

6. Logoyda, L. Validation of chromatographic methods of analysis for the determination of active pharmaceutical ingredients in different medicines. Pharma. School Association for Pharmaceutical Development and Scientific Research, 34. 


\section{РОЗРОБКА І МЕТОДОЛОГІЯ ВИЗНАЧЕННЯ БІСОПРОЛОЛУ В ЛІКАРСЬКИХ ЗАСОБАХ}

\section{Резюме}

Вступ. Кількість препаратів, які випускає фрармацевтична промисловість, зростає з кожним роком. Ці лікарські засоби можуть бути як оригінальними, так і з частковою модифрікацією вже існуючого препарату. Метою будь-якого аналітичного вимірювання є отримання послідовних, надійних і точних даних. Тонкошарова хроматографрія (ТШХ) - метод аналізу сумішей шляхом розділення. Вона може бути використана для ідентифрікації речовин та встановлення їх чистоти.

мета дослідження. Аналіз бісопрололу описано у фармакопеї, але мета даного дослідження полягала в розробці простішого, селективнішого, точнішого, надійнішого, дешевшого ТШХ-методу його визначення в лікарських засобах і використанні цього методу для аналізу метаболітів на наступному етапі досліджень.

Методи дослідження. У даній роботі було вивчено системи розчинників для визначення бісопрололу методом тонкошарової хроматографрії.

Результати й обговорення. За допомогою тонкошарової хроматографрії було розроблено метод ідентифрікації бісопрололу в лікарських засобах. Встановлено, що найбільш оптимальним Rf $\epsilon$ cuстема розчинників аміак (25 \%) - пропанол (30:70). Межа виявлення бісопрололу в цій системі становила 0,4 мка. Було досліджено валідаційні характеристики - специфрічність і придатність хроматографрічної системи, критерії прийнятності встановлено відповідно до ДФУ.

Висновок. Розроблено хроматографічний метод ідентифікації бісопрололу в лікарських засобах. Запропонований метод є економічним, простим і може бути застосований для аналізу лікарських фрорм.

КЛЮЧОВІ СЛОВА: бісопролол; лікарські засоби; ідентифікація; тонкошарова хроматографрія; валідація.

ТЕРНОПОЛЬСКИЙ ГОСУДАРСТВЕННЫЙ МЕДИЦИНСКИЙ УНИВЕРСИТЕТ ИМЕНИ И. Я. ГОРБАЧЕВСКОГО

\section{РАЗРАБОТКА И МЕТОДОЛОГИЯ ОПРЕДЕЛЕНИЯ БИСОПРОЛОЛА В ЛЕКАРСТВЕННЫХ СРЕДСТВАХ}

\section{Резюме}

Вступление. Количество препаратов, которые выпускает фрармацевтическая промышленность, растет с каждым годом. Эти лекарственные средства могут быть как оригинальными, так и с частичной модификацией уже существующего препарата. Целью любого аналитического измерения является получение последовательных, надежных и точных данных. Тонкослойная хроматограсрия (TCX) - метод анализа смесей путем разделения. Она может быть использована для идентификации веществ и установления их чистоты.

Цель исследования. Анализ бисопролола описан в фрармакопеи, но цель данного исследования заключалась в разработке более простого, селективного, точного, надежного, дешевого ТСХ-метода его определения в лекарственных средствах и использовании этого метода для анализа метаболитов на следующем этапе исследований.

Методы исследования. В данной работе было изучено системы растворителей для определения бисопролола методом тонкослойной хроматограсрии.

Результаты и обсуждение. С помощью тонкослойной хроматографрии был разработан метод идентияикации бисопролола в лекарственных средствах. Установлено, что наиболее оптимальным Rf является система растворителей аммиак (25 \%) - пропанол (30:70). Предел выявления бисопролола в этой системе составлял 0,4 мка. Было исследовано валидационные характеристики - специяичность и пригодность хроматографической системы, критерии приемлемости установлено в соответствии с ГФу.

Вывод. Разработан хроматографический метод идентификации бисопролола в лекарственных средствах. Предложенный метод является экономичным, простым и может быть применен для анализа лекарственных форм.

КЛЮЧЕВЫЕ СЛОВА: бисопролол; лекарственные средства; идентификация; тонкослойная хроматография; валидация.

Address for correspondence: L. S. Logoyda, I. Horbachevsky Ternopil State Medical University, Maidan Voli, 1, Ternopil, 46001, Ukraine, e-mail: logojda@tdmu.edu.ua. 